\title{
Optimasi Molase dan Tibicos sebagai Media Fermentasi dalam Memproduksi Nutraceutical Feed Additive Menggunakan Response Surface Methodology (RSM)
}

\author{
Mustofa Hilmi*, Anis Usfah Prastujati \\ Program Studi Teknologi Pengolahan Hasil Ternak, Politeknik Negeri Banyuwangi \\ J1. Raya Jember-Banyuwangi KM 13 Labanasem, Kabat, Banyuwangi \\ *Email korespondensi: mustofahilmi@ poliwangi.ac.id
}

(Diterima: 13-08-2019; disetujui 10-12-2019)

\begin{abstract}
ABSTRAK
Molase merupakan hasil samping industri gula tebu yang biasa digunakan dalam proses fermentasi. kandungan molase seperti sukrosa bisa digunakan media pertumbuhan bakteri asam laktat dan yeast sebagai sumber probiotik ternak. Optimasi parameter fermentasi molase memegang peranan yang penting dalam keberhasilan dalam menghasilkan komponen bahan organik, disamping jenis mikroorganisme yang digunakan. Penambahan konsentrasi inokulum (tibicos), konsentrasi molase, dan lama fermentasi menjadi hal yang utama untuk dioptimasi agar bakteri asam laktat dan asam organik dihasilkan optimal dan waktunya efisien menggunakan response surface methodology (RSM). Metode RSM berguna untuk menentukan nilai-nilai perlakuan (molase, tibicos, lama fermentasi dengan respon optimal terdiri dari 15 perlakuan faktorial bertujuan untuk menentukan variabel tetap dan variabel bebas. Penambahan tibicos dan lama fermentasi berpengaruh signifikan $(\mathrm{P}<0,05)$ terhadap jumlah bakteri asam laktat, namun interaksi antara konsentrasi molase dan kosentrasi tibicos $(\mathrm{P}<0,05)$ memberikan pengaruh yang signifikan terhadap respon pada tingkat probabilitas 95\%. Interaksi kosentrasi tibicos dan lama fermentasi $(\mathrm{P}<0,05)$ memberikan pengaruh yang signifikan terhadap jumlah bakteri asam laktat. hasil optimasi, diperoleh nilai optimum kosentrasi molase 12,5\%, Kosentrasi tibicos $10 \%$ dan waktu fermentasi 36 jam. Kondisi optimum tersebut diprediksi menghasilkan bakteri asam laktat dan prosentasi asam laktat sebesar 7,30333 log CFU/ml dan 0,386667\%.
\end{abstract}

Kata kunci: fermentasi, molase, tibicos, RSM

\begin{abstract}
ABSTRAK
Molasses is a by-product of the cane sugar industry which is commonly used in the fermentation process. Molasses such as sucrose can be used as a growth media for lactic acid bacteria and yeast as a source of animal probiotics. Optimization of molasses fermentation parameters plays an essential role in the success in producing components of organic matter, in addition to the types of microorganisms used. The RSM method is useful for determining treatment values (molasses, tibicos, fermentation time with optimal responses consisting of 15 factorial treatments aimed at determining fixed variables and independent variables. The addition of tibicos and fermentation time has a significant effect $(\mathrm{P}<0.05)$ on the number of bacteria lactic acid, but the interaction between the concentration of molasses and the concentration of tibicos $(\mathrm{P}<0.05)$ has a significant influence on the response at a probability level of $95 \%$. Lactic acid optimization results obtained the optimum value of molasses concentration $12.5 \%$, tibicos concentration $10 \%$ and fermentation time of 36 hours. The optimum conditions are predicted to produce lactic acid bacteria and lactic acid percentage of $7.30333 \log \mathrm{CFU} / \mathrm{ml}$ and $0.386667 \%$.
\end{abstract}

Keywords: fermentation, molasses, tibicos, RSM

\section{PENDAHULUAN}

Molase (tetes tebu) merupakan hasil samping industri gula tebu yang biasa digunakan dalam proses fermentasi akan tetapi pemanfaatan molase ini belum optimal dimasyarakat yang menyebabkan molase menjadi limbah yang dapat mencemari 
lingkungan, sehingga menambah biaya pengeluaran pabrik gula dalam menanggulangi dampak tersebut (Misran, 2005). Untuk mengatasi dampak pencemaran lingkungan, molases bisa dimanfaatkan sebagai media pertumbuhan bakteri asam laktat (BAL) dan ragi sebagai sumber probiotik ternak karena mengandung senyawa seperti sukrosa, glukosa, fruktosa, karbohidrat lainnya, nitrogen, lemak, fosfolopid, pigmen dan vitamin yang dibutuhkan dalam perkembangbiakan bakteri (Dumbrepatil et al., 2008; Cao et al., 2010; Toghyani et al., 2015). Kandungan senyawa dan nutrisi molase ini bisa dimanfaatkan sebagai produk olahan fermentasi dengan memperkembangbiakan bakteri asam laktat dan yeast serta menghasilkan metabolit sekunder sebagai sumber probiotik, nutrien dan antioksidan yang dibutuhkan bagi ternak, salah satunya produk olahan kefir dengan penambahan biji tibicos (water kefir grain) sebagai starter yang disebut kefir molases (Ghazzay, 2014; Toghyani et al., 2015).

Kefir molase merupakan hasil fermentasi molases yang mengandung sukrosa, glukosa, fruktosa, karbohidrat lainnya, nitrogen dan mineral sebagai sumber makanan bakteri asam laktat dan yeast dengan menambahkan tibicos (water kefir grain) sebagai starter. Tibicos (water kefir grain) merupakan starter kefir fermentasi yang mengandung beberapa exopolysaccharides (EPS) yang sering disebut kefiran, serta mengandung berbagai mikroorganisme yang menguntungkan bagi tubuh (Marquina et al., 2002; Dumbrepatil et al., 2008). Menurut Wang et al. (2008) dan Plessas et al. (2016) bahwa kefiran merupakan heteropolisakarida (EPS) yang terdiri dari glukosa dan galaktosa dalam konsentrasi yang tinggi, dan itu diklasifikasikan sebagai glucogalactan larut dalam dan meningkatkan sifat gel, serta berkumpulnya bermacam-macam mikroorganisme simbiosis termasuk yeast (ragi) (Kluyveromyces, Candida, Saccharomyces, dan Pichia), bakteri asam laktat (BAL) (Lactobacillus, Lactococcus, Leuconostoc, Streptococcus), dan sedikit bakteri asam asetat (Witthuhn et al., 2005), bakteri-bakteri yang ini nantinya sebagai sumber probiotik.

Keuntungan dari BAL, ragi, dan bakteri asam asetat sebagai probiotik dapat menghambat perkembangan mikroorganisme patogen, karena mikroba yang terkandung dalam biji kefir (starter) mampu menghasilkan asam laktat dan asam asetat, etanol, peptida (bakteriosin), dan komponen biologis aktif lainnya (Witthuhn et al., 2005). Probiotik dan hasil metabolit ini bisa dijadikan nutraceutical feed additive yang merupakan imbuhan pakan (atau bagian dari makanan) yang memberikan manfaat medis atau kesehatan, termasuk pencegahan, pengobatan penyakit serta meningkatkan performa, dan produksi ternak (Bhattacharya, 2015).

Optimasi parameter fermentasi molase memegang peranan yang penting dalam keberhasilan dalam menghasilkan komponen bahan organik, disamping jenis mikroorganisme yang digunakan. Penambahan konsentrasi inokulum (tibicos), konsentrasi molase, dan lama fermentasi menjadi hal yang utama untuk dioptimasi agar bakteri asam laktat dan asam organik dihasilkan optimal dan waktunya efisien menggunakan response surface methodology (RSM). Metode RSM berguna untuk menentukan nilai-nilai perlakuan (molase, tibicos, lama fermentasi dengan respon optimal. Desain eksperimen RSM memungkinkan untuk melakukan percobaan dalam jumlah yang sedikit. Pengaruh semua perlakuan dianalisis secara bersamaan dan pengaruh interaksinya berdasarkan respon yang diinginkan (Sudjana, 2002; De castro et al., 2009). Hasil analisis program RSM ditampilkan dalam bentuk kontur yang menghasilkan titik optimum (kondisi optimum) berupa optimasi maksimum, minimum atau saddle point (Myers et al., 2016). Beberapa penelitian yang menggunakan RSM dengan melibatkan penambahan konsentrasi inokulum mikroorganisme dan lama fermentasi pada mediam molase telah dilakukan (El-Gendy et al., 2013; Mahazar et al., 2017), namun penelitian terkait dengan optimasi fermentasi pada bahan molase yang difermentasi dengan tibicos masih belum banyak dilakukan. Penelitian ini bertujuan untuk mengoptimasi kondisi produksi feed additive (level inokulum tibicos, waktu inkubasi, dan level molase) menggunakan RSM terhadap kandungan bakteri asam laktat dan asam laktat.

\section{MATERI DAN METODE}

\section{Materi Penelitian}

Material yang digunakan dalam penelitian adalah molase dari PT. Industri Gula Glenmore Banyuangi, dan inokulan (tibicos) dari Laboratorium Teknologi Pengolahan hasil Ternak, Politeknik Negeri Banyuwangi.

\section{Metode Penelitian}

Percobaan (formulasi) dan analisa data pada penelitian ini menggunakan teknik response surface methodology pada konstruksi Box-Behnken menggunakan program design expert 11 yang terdiri dari 15 perlakuan faktorial bertujuan untuk menentukan variabel tetap dan variabel bebas (Myers et al., 2016). Variabel tetap terdiri dari 
jumlah bakteri asam laktat $\left(\mathrm{Y}_{1}\right)$ dan prosentasi asam laktat $\left(\mathrm{Y}_{2}\right)$. Faktor perlakuan sebagai variabel independen adalah dari kosentrasi molase sebagai faktor $1\left(\mathrm{X}_{1}\right)$, kosentrasi tibicos sebagai faktor $2\left(\mathrm{X}_{2}\right)$ dan lama fermentasi sebagai faktor $2\left(\mathrm{X}_{3}\right)$ (Tabel 1). Untuk melakukan optimasi menggunakan RSM maka nilai dari variabel independen harus ditransformasi menjadi variabel terkode (coded variables) (Tabel 2).

Pembuatan molase fermentasi dengan tahapan pemanasan air dengan suhu $80^{\circ} \mathrm{C}$ selama 10 menit dengan penambahan molase sesuai rancangan RSM (Tabel 2). Kemudian suhu diturunkan sekitar $35-40^{\circ} \mathrm{C}$ dengan perendaman beaker glass yang berisi campuran air dan molase ke dalam air dingin. Tahap selanjutnya penambahan inokulasi tibicos starter (water kefir grain) sesuai perlakuan (Tabel 2). Setelah proses inokulasi selesai dilanjutkan dengan inkubasi fermentasi molase anaerob selama waktu sesuai dengan analisa RSM dengan suhu antara $25-35^{\circ} \mathrm{C}$ selama waktu $24-48$ jam sesuai dengan analisa RSM (Tabel 2).

Pada akhir proses fermentasi, setiap waktu 12 jam dilakukan pengambilan sampel untuk dianalisa kadar asam laktat. Sampel hasil fermentasi disentrifugasi pada kecepatan 7.000 rpm selama 5 menit, kemudian disaring menggunakan kertas saring berdiameter pori $0,22 \mu \mathrm{m}$ dan dibekukan pada suhu $-4^{\circ} \mathrm{C}$. Supernatan hasil sentrifugasi kemudian dianalisis kandungan asam laktat dengan High Performance Liquid Chromatography (HPLC) menggunakan kolom Transgenomic ION300 column (Transgenomic, Inc.) (Nurdyansyah \& Hasbullah. 2018). Elusi isokratik dengan laju ratarata $0,4 \mathrm{~mL} /$ menit, fase bergerak menggunakan $\mathrm{H}_{2} \mathrm{SO}_{4} 0,0025 \mathrm{M}$ bersuhu $65^{\circ} \mathrm{C}$ dengan menggunakan detektor refraction index (RI).

Table 1. Penentuan variabel bebas dan kode perlakuan pada penelitian

\begin{tabular}{ccccc}
\hline \multirow{2}{*}{ Variabel bebas } & Simbol & \multicolumn{3}{c}{ Range \& level } \\
\cline { 3 - 5 } & & 10 & 0 & 1 \\
\hline Kosentrasi Molase (\%) & X1 & 5 & 10 & 15 \\
Kosentrasi Tibicos (\%) & X2 & 24 & 36 & 15 \\
Lama Fermentasi (Jam) & X3 & & & 48 \\
\hline
\end{tabular}

Table 2. Rancangan perlakuan menggunakan response surface methodology (RSM) berdasarkan kontruksi Box-Behnken

\begin{tabular}{ccccccc}
\hline Run & \multicolumn{3}{c}{$\begin{array}{c}\text { Variabel Terkode } \\
\text { (coded variables) }\end{array}$} & Molase (\%) & Tibicos (\%) & $\begin{array}{c}\text { Lama Fermentasi } \\
(\text { Jam })\end{array}$ \\
\hline 1 & 1 & 0 & 1 & 15 & 10 & 48 \\
2 & 0 & -1 & -1 & 12,5 & 5 & 24 \\
3 & 1 & -1 & 0 & 15 & 5 & 36 \\
4 & 0 & -1 & 1 & 12,5 & 5 & 48 \\
5 & 0 & -1 & 0 & 10 & 5 & 36 \\
6 & 0 & 1 & -1 & 12,5 & 15 & 24 \\
7 & 0 & 0 & 0 & 12,5 & 10 & 36 \\
8 & -1 & 0 & -1 & 10 & 10 & 24 \\
9 & -1 & 1 & 0 & 10 & 15 & 36 \\
10 & 0 & 0 & 0 & 12,5 & 10 & 36 \\
11 & 0 & 0 & 0 & 12,5 & 10 & 36 \\
12 & 1 & 1 & 0 & 15 & 15 & 36 \\
13 & 1 & 0 & -1 & 15 & 10 & 24 \\
14 & -1 & 0 & 1 & 10 & 10 & 48 \\
15 & 0 & 1 & 1 & 12,5 & 15 & 48 \\
\hline
\end{tabular}


Tabel 3. Desain eksperimen RSM kandungan jumlah asam laktat molase fermentasi

\begin{tabular}{cccccc}
\hline Run & $\begin{array}{c}\text { Molase } \\
(\%)\end{array}$ & $\begin{array}{c}\text { Tibicos } \\
(\%)\end{array}$ & $\begin{array}{c}\text { Lama Fermentasi } \\
(\text { Jam })\end{array}$ & $\begin{array}{c}\text { Bakteri Asam Laktat }(\log \\
\text { CFU/ml })\end{array}$ & Asam laktat (\%) \\
\hline 1 & 15 & 10 & 48 & 7,49 & 0,453 \\
2 & 12,5 & 5 & 24 & 5,18 & 0,184 \\
3 & 15 & 5 & 36 & 7,47 & 0,354 \\
4 & 12,5 & 5 & 48 & 7,39 & 0,336 \\
5 & 10 & 5 & 36 & 6,25 & 0,193 \\
6 & 12,5 & 15 & 24 & 7,14 & 0,379 \\
7 & 12,5 & 10 & 36 & 7,27 & 0,33 \\
8 & 10 & 10 & 24 & 6,27 & 0,26 \\
9 & 10 & 15 & 36 & 8,38 & 0,39 \\
10 & 12,5 & 10 & 36 & 7,22 & 0,49 \\
11 & 12,5 & 10 & 36 & 7,42 & 0,34 \\
12 & 15 & 15 & 36 & 6,76 & 0,197 \\
13 & 15 & 10 & 24 & 8,16 & 0,388 \\
14 & 10 & 10 & 48 & 8,85 & 0,574 \\
15 & 12,5 & 15 & 48 & 7,96 & 0,328 \\
\hline
\end{tabular}

Analisa jumlah bakteri asam laktat, dilakukan dengan prosedur yaitu larutan molase yang sudah difermentasi diencerkan menjadi $0,1 \%$ larutan $9 \mathrm{ml}$ pepton (larutan ini adalah $10^{-1}$ pengenceran), kemudian dilanjutkan peng-enceran ke $10^{-8}$. Dalam tiga seri terakhir pengenceran, sampel diambil masing-masing $1 \mathrm{ml}$ dan dituangkan ke dalam cawan petri yang diisi dengan media MRSA. Media MRSA yang berisi sampel diinkubasi dengan suhu dan waktu inkubasi sesuai perlakuan. Pertumbuhan koloni di setiap cawan petri dihitung sesuai dengan waktu inkubasi. Menghitung jumlah bakteri asam laktat dalam $1 \mathrm{~g}$ dengan mengalikan jumlah rata-rata koloni dengan faktor pengenceran yang digunakan dengan unit pembentuk koloni/g (Nurdyansyah \& Hasbullah, 2018).

\section{HASIL DAN PEMBAHASAN}

\section{Pengembangan model untuk memprediksi jumlah bakteri asam laktat dan asam laktat}

Penambahan tibicos dan lama fermentasi berpengaruh signifikan $(\mathrm{P}<0,05)$ terhadap jumlah bakteri asam laktat, namun interaksi antara konsentrasi molase dan kosentrasi tibicos $(\mathrm{P}<0,05)$ memberikan pengaruh yang signifikan terhadap respon pada tingkat probabilitas 95\% (Tabel 4). Interaksi kosentrasi tibicos dan lama fermentasi $(\mathrm{P}<0,05)$ memberikan pengaruh yang signifikan terhadap jumlah bakteri asam laktat. Sedangkan dari hasil analisis varians, ada dua uji untuk memeriksa uji signifiansi yaitu uji simultan dan uji lack of $f i$ untuk bakteri asam laktat dan asam laktat masingmasing Nilai P-value sebesar 0,0729 dan 0,7095 $(\mathrm{P}>0,05)$ yang mengindikasikan bahwa model dapat mendeskripsikan data respon jumlah bakteri asam laktat dan asam laktat sehingga dapat disimpulkan bahwa model yang didapat cocok digunakan untuk memprediksikan kondisi proses fermentasi yang menghasilkan kandungan bakteri asam laktat dan asam laktat yang optimum. Jika nilai Lack of Fit signifikan $(P<0,05)$ maka model linier lebih sesuai untuk menduga nilai respon (Wahyono et al., 2018). Adanya perbedaan antara nilai $\mathrm{R}^{2}$ dan Adjusted $\mathrm{R}^{2}$ diduga disebabkan oleh munculnya penambahan variabel yang tidak signifikan dalam pembangunan model. Penurunan nilai Adjusted $\mathrm{R}^{2}$ akan terjadi jika variabel yang ditambahkan pada permodelan tidak berpengaruh (Montgomery, 2001). Berdasarkan model kuadratik, variabel kosentrasi molase, kosentrasi tibicos, dan lama fermentasi dengan jumlah kandungan bakteri asam laktat dan asam laktat memiliki keeratan yang tinggi yang ditunjukkan dengan nilai koefisien determinasi $\left(\mathrm{R}^{2}\right)$ masing-masing sebesar 0,967 dan 0,8306. Hal tersebut menunjukkan bahwa model kuadratik mampu menjelaskan dengan yang berarti keeratan hubungan antara konsentrasi molase, konsentrasi tibicos dan lama fermentasi terhadap respon jumlah bakteri asam laktat sebesar 96,7\% dan 83,06\% (Myers et al., 2016). Nilai lack of fit untuk jumlah bakteri asam laktat sebesar 0,0729 (P>0,05) yang berarti tidak signifikan yang menunjukkan bahwa model kuadratik sangat sesuai untuk menduga variabel respon ( Hadiyanto \& Suttrisnorhadi, 2016; Myers et al., 2016). 
Tabel 4. Analisis varians berdasarkan respon surface dengan model kuadratik untuk jumlah bakteri asam laktat dan asam laktat

\begin{tabular}{|c|c|c|c|c|c|c|c|c|}
\hline \multirow[b]{2}{*}{ Source } & \multicolumn{4}{|c|}{ Bakteri Asam laktat } & \multicolumn{4}{|c|}{ Asam laktat } \\
\hline & $\begin{array}{l}\text { Predicted } \\
\text { Coefficients }\end{array}$ & $\begin{array}{l}\text { Standard } \\
\text { Error }\end{array}$ & $\mathrm{df}$ & P-value & $\begin{array}{l}\text { Predicted } \\
\text { Coefficients }\end{array}$ & $\begin{array}{l}\text { Standard } \\
\text { Error }\end{array}$ & $\mathrm{df}$ & P-value \\
\hline Model & 7,3 & 0,1714 & 9 & 0,0046 & 0,3867 & 0,04368 & 9 & 0,1410 \\
\hline $\mathrm{X}_{1}$ & 0,0162 & 0,1050 & 1 & 0,883 & $-0,0031$ & 0,02675 & 1 & 0,9115 \\
\hline $\mathrm{X}_{2}$ & 0,4937 & 0,1050 & 1 & 0,0053 & 0,0284 & 0,02675 & 1 & 0,3373 \\
\hline $\mathrm{X}_{3}$ & 0,6175 & 0,1050 & 1 & 0,002 & 0,0600 & 0,02675 & 1 & 0,0749 \\
\hline $\mathrm{X}_{1} \mathrm{X}_{2}$ & $-0,7100$ & 0,1484 & 1 & 0,005 & $-0,0885$ & 0,03783 & 1 & 0,0664 \\
\hline $\mathrm{X}_{1} \mathrm{X}_{3}$ & $-0,8125$ & 0,1484 & 1 & 0,0028 & $-0,0622$ & 0,03783 & 1 & 0,1608 \\
\hline $\mathrm{X}_{2} \mathrm{X}_{3}$ & $-0,3475$ & 0,1484 & 1 & 0,0663 & $-0,0508$ & 0,03783 & 1 & 0,2374 \\
\hline $\mathrm{X}_{1}^{2}$ & 0,3433 & 0,1545 & 1 & 0,0769 & 0,0044 & 0,03937 & 1 & 0,9150 \\
\hline $\mathrm{X}_{2}^{2}$ & $-0,4317$ & 0,1545 & 1 & 0,0383 & $-0,1076$ & 0,03937 & 1 & 0,0412 \\
\hline $\mathrm{X}_{3}^{2}$ & 0,0458 & 0,1545 & 1 & 0,7786 & 0,02770 & 0,03937 & 1 & 0,5136 \\
\hline $\mathrm{R}^{2}$ & \multicolumn{4}{|c|}{0,9670} & \multicolumn{4}{|c|}{0,8306} \\
\hline Adjusted $\mathrm{R}^{2}$ & \multicolumn{4}{|c|}{0,8955} & \multicolumn{4}{|c|}{0,5258} \\
\hline Lack of Fit & \multicolumn{4}{|c|}{0,0729} & \multicolumn{4}{|c|}{0,7095} \\
\hline
\end{tabular}

Keterangan: $\mathrm{X}_{1}$ : Kosentrasi molase (\%); $\mathrm{X}_{2} ;$ Kosentrasi Tibicos (\%); $\mathrm{X}_{3}$; lama Fermentasi (jam)

\section{Pengaruh molase, tibicos, dan lama fermentasi terhadap jumlah bakteri asam laktat dan asam laktat}

Gambar 1 dan Gambar 2 dapat dilihat bahwa bentuk kurva saddle yang menggambarkan kemungkinan dari variabel pada poin maksimum dan minimum. Hasil ini menunjukkan bahwa interaksi konsentrasi molase dan konsentrasi tibicos berpengaruh nyata $(\mathrm{P}<0,05)$, sedangkan interakasi molase dan waktu mempengaruhi populasi bakteri asam laktat serta waktu (Tabel 4) terhadap jumlah bakteri asam laktat. Berpengaruh jumlah bakteri asam laktat dan molase disebabkan tingginya kosentrasi tibicos yg berdampak peningkatan jumlah bakteri asam laktat yg terkandung di dalam tibicos. Menurut Hilmi et al. (2019) bahwa meningkatnya jumlah bakteri asam laktat disebabkan oleh meningkatnya kadar konsentrasi inokulan dan keberadaan sumber gula yang ditambahan $10 \%$ molase sebagai sumber sukrosa yang terkandung dalam perlakuan.

Gambar 3 dan Gambar 4 terdapat hubungan interaksi konsentrasi molase dan konsentrasi tibicos tidak berpengaruh $(\mathrm{P}>0,05)$, sedangkan interakasi molase dan waktu mempengaruhi populasi prosentase asam laktat serta waktu (Tabel 4) terhadap prosentase bakteri asam laktat. Peningkatan asam laktat pada Gambar 3 dan 4 didapatkan pada penambahan tibicos sejumlah $15 \%$ dan $10 \%$ molases dengan lama waktu 48 jam. Peningkatan jumlah asam laktat ini disebabkan meningkatnya populasi bakteri asam

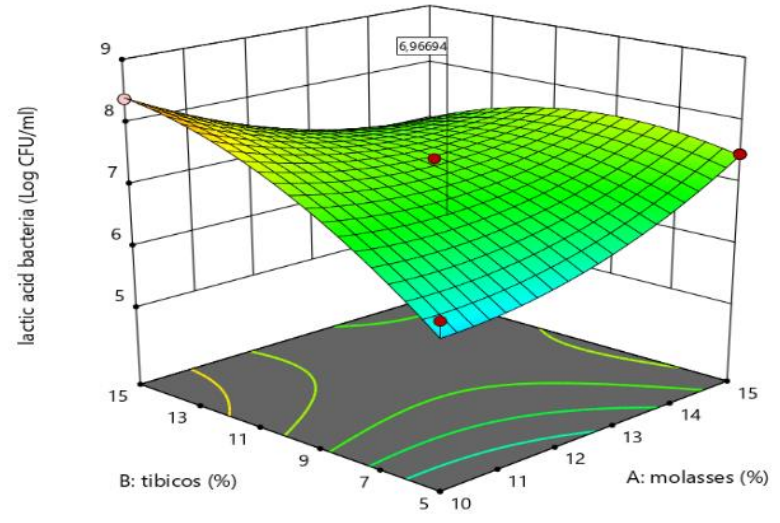

Gambar 1. Response surface menunjukkan pengaruh perbedaan konsentrasi molase dan tibicos terhadap jumlah bakteri asam laktat



Gambar 2. Response Surface menunjukkan pengaruh perbedaan konsentrasi molase dan waktu fermentasi terhadap jumlah bakteri asam laktat 
dengan memanfaatkan sumber molase sebagai sumber energi. Menurut Laureys \& De Vuyst (2017) bahwa penambahan sumber karbon selama 48 jam untuk proses pertumbuhan bakteri asam laktat dalam media fermentasi akan lebih optimal dalam proses peningkatan populasi bakteri asam laktat. Menurut Nurdyansyah dan Hasbullah (2018) penambahan sumber gula akan tampak berupa peningkatan biomassa sel serta peningkatan metabolit sekunder berupa senyawa asam laktat dan asam-asam organik lainnya.

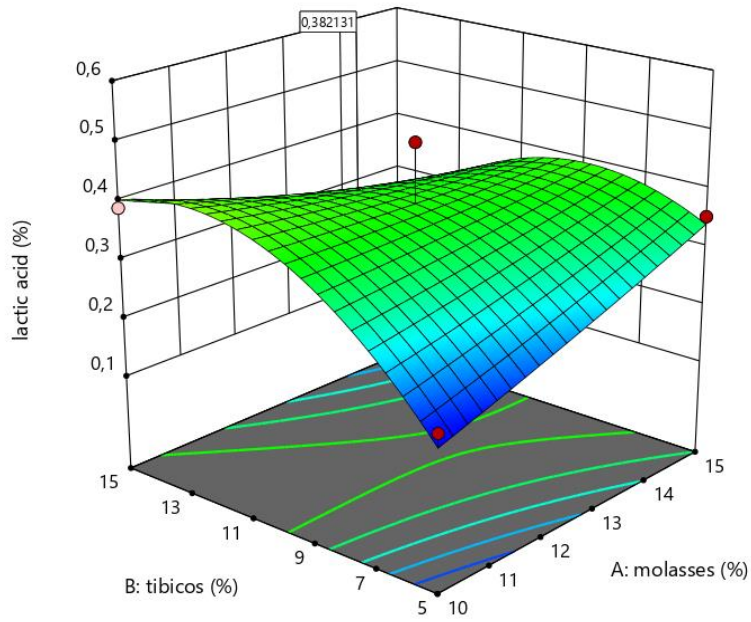

Gambar 3. Response surface menunjukkan pengaruh perbedaan $k$ onsentrasi molase dan tibicos

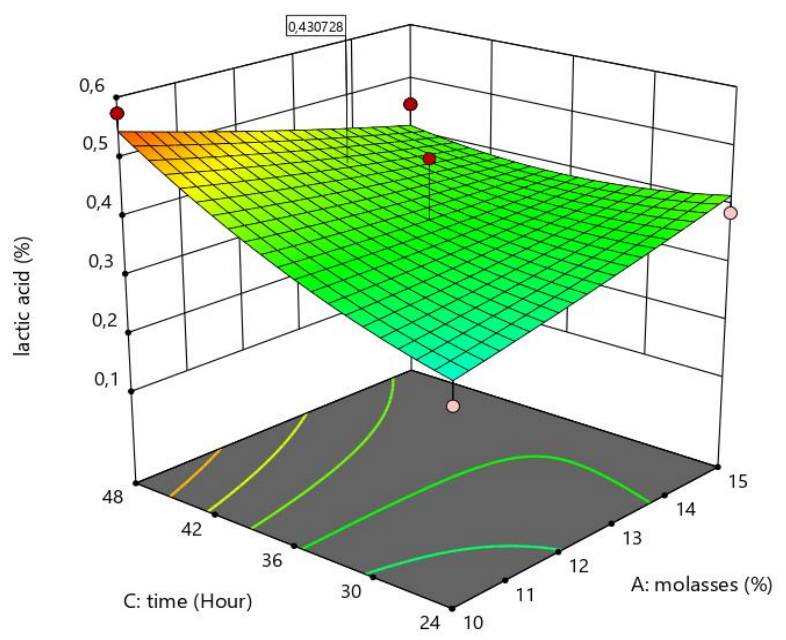

Gambar 4. Response surface menunjukkan pengaruh perbedaan konsentrasi molase dan waktu fermentasi terhadap jumlah asam laktat

\section{KESIMPULAN}

Model prediksi penambahan kosentrasi molase, kosentrasi tibicos, dan lama fermentasi dengan jumlah kandungan bakteri asam laktat dan asam laktat memiliki keeratan yang tinggi yang ditunjukkan dengan nilai koefisien determinasi $\left(\mathrm{R}^{2}\right)$ masing-masing sebesar 0,9670 dan 0,8306 . Hasil optimasi diperoleh nilai optimal molase $12,5 \%$, tibicos $10 \%$ dan lama waktu 36 jam menghasilkan 7,625 $\log$ CFU/ml, asam laktat 0,386667\%.

Model prediksi penambahan kosentrasi molase, kosentrasi tibicos, dan lama fermentasi dengan jumlah kandungan bakteri asam laktat dan asam laktat memiliki keeratan yang tinggi yang ditunjukkan dengan nilai koefisien determinasi $\left(\mathrm{R}^{2}\right)$ masing-masing sebesar 0,967 dan 0,8306. Hasil optimasi diperoleh nilai optimal molase $12,5 \%$, tibicos $10 \%$ dan lama waktu 36 jam menghasilkan bakteri asam laktat 7,625 log CFU/ml, asam laktat $0,386667 \%$.

\section{UCAPAN TERIMA KASIH}

Penulis mengucapkan terimakasih kepada Kementerian Riset, Teknologi dan Pendidikan Tinggi Republik Indonesia yang telah memberikan Hibah Penelitian Dosen Pemula Nomor 018/SP2H/LT/DRPM/2019, dan kepada Ketua Lembaga Penelitian dan Pengabdian kepada Masyarakat Politeknik Negeri Banyuwangi dalam membantu pelaksanaan penelitian.

\section{DAFTAR PUSTAKA}

Bhattacharya, A. 2015. Nutraceuticals in Livestock and Poultry. New India Publishing Agency. New Delhi.

Cao, Y., T. Takahashi, K-i Horiguchi, \& N. Yoshida. 2010. Effect of adding lactic acid bacteria and molasses on fermentation quality and in vitro ruminal digestion of total mixed ration silage prepared with whole crop rice. Grassl Sci. 56(1):19-25. https:// doi.org/10.1111/j.1744-697X.2009.00168.x.

Cappuccino, J.G. \& N. Sherman. 2013. Microbiology: A Laboratory Manual. Benjamin-Cummings Publishing Company. California.

Dumbrepatil, A., M. Adsul, S. Chaudhari, J. Khire, \& D. Gokhale. 2008. Utilization of molasses sugar for lactic acid production by lactobacillus delbrueckii subsp. delbrueckii mutant uc-3 in batch fermentation. Appl Environ Microbiol. 74(1):333-335. https:// doi.org/10.1128/AEM.01595-07.

El-Gendy, N.S., H.R. Madian, \& S.S.A. Amr. 2013. Design and optimization of a process for sugarcane molasses fermentation by saccharomyces cerevisiae using response surface methodology. Int $\mathrm{J}$ Microbiol. 
Article ID 815631. https://doi.org/10.1155/ 2013/ 815631.

Ghazzay, M.H. 2014. Propagation of kefir in various sugar media. Int J Bas Appl Sci. $14: 41-45$.

Hadiyanto, H. \& Suttrisnorhadi. 2016. Response surface optimization of ultrasound assisted extraction (UAE) of phycocyanin from microalgae Spirulina platensis. Emirates Journal of Food and Agriculture 28(4):227-234. https://doi.org/10.9755/ ejfa.2015-05-193.

Hilmi, M., A.U. Prastujati, A. Khusna. M.H. Khirzin, \& D. Yannuarista. 2019. Effects add kefir grains to whey cheese on chemical and microbiological qualities. Jurnal Ilmu-ilmu Peternakan 29(1):46-55. https://doi.org/ 10.21776/ub.jiip.2019.029.01.06.

Laureys, D. \& L. De Vuyst. 2017. The water kefir grain inoculum determines the characteristics of the resulting water kefir fermentation process. J Appl Microbiol. 122(3):719-732.

Mahazar, N.H., Z. Zakuan, H. Norhayati, A.S. MeorHussin, \& Y. Rukayadi. 2017. Optimization of culture medium for the growth of Candida sp. and Blastobotrys sp. as starter culture in fermentation of cocoa beans (Theobroma cacao) using Response Surface Methodology (RSM). Pakistan Journal of Biological Science 20(3):154-159. https://doi.org/10.3923/pjbs.2017.154.159.

Marquina, D., A. Santos, I. Corpas, J. Munoz, J. Zazo, \& J.M. Peinado. 2002. Dietary influence of kefir on microbial activities in the mouse bowel. Lett Appl Microbiol. 35(2):136-140. https://doi.org/10.1046/j/ 1472765x.2002.01155.x.

Misran, E. 2005. Industri tebu menuju zero waste industry. Industri Tebu Menuju Zero Waste Industry. Jurnal Teknologi Proses 4(2):6-10.

Montgomery, D.C. 2001. Design and analysis of experiments. John Wiley \& Sons. New York.

Myers, R.H., D.C. Montgomery, \& C.M. AndersonCook. 2016. Response Surface Methodology: Process and Product Optimization Using Designed Experiments. John Wiley \& Sons. New York.

Nurdyansyah, F. \& U.H.A. Hasbullah. 2018. Optimasi fermentasi asam laktat oleh lactobacillus casei pada media fermentasi yang disubtitusi tepung kulit pisang. AlKauniyah 11(1):64-71.

Plessas, S., C. Nouska, I. Mantzourani, Y. Kourkoutas, A. Alexopoulos, \& E. Bezirtzoglou. 2016. Microbiological exploration of different types of kefir grains. Fermentation 3(1):1. https://doi.org/10.3390/fermentation3010 001.

Toghyani, M., S. Mosavi, M. Modaresi, \& N. Landy. 2015. Evaluation of kefir as a potential probiotic on growth performance, serum biochemistry and immune responses in broiler chicks. Animal Nutrition. 1(4):305309. https://doi.org/10.1016/j.aninu.2015. 11.010 .

Wahyono, A. E. Kurniawati, Kasutjianingsih, P. Kang-Hyun, K. Woo-Won. Optimasi proses pembuatan tepung labu kuning menggunakan response surface methodology untuk meningkaatkan aktivitas antioksidannya. Jurnal Teknologi dan Industri Pangan 29(1):29-38. https://doi.org/ 10.6066/ jtip.2018. 29.1.29.

Wang S.Y., H.C. Chen, J.R. Liu, Y.C. Lin, \& M.J. Chen. 2008. Identification of yeasts and evaluation of their distribution in Taiwanese kefir and viili starters. J Dairy Sci. 91(10):3798-3805.

Witthuhn, R., T. Schoeman, \& T. Britz. 2005. Characterisation of the microbial population at different stages of Kefir production and Kefir grain mass cultivation. Int Dairy J. 15(4):383-389. 